\title{
Arhythmorhynchus comptus (Acanthocephala: Polymorphidae) from shorebirds in Patagonia, Argentina, with some comments on a species of Profilicollis
}

\author{
Sofia Capasso* and Julia I. Diaz \\ Centro de Estudios Parasitológicos y de Vectores (FCNyM, UNLP, CONICET), Calle 120 s/n e/ 61 y 64, 1900, La Plata, Buenos Aires \\ Province, Argentina \\ * Corresponding author. E-mail: scapasso@cepave.edu.ar
}

\begin{abstract}
Adult and immature Arhythmorhynchus comptus (Acanthocephala: Polymorphidae) were found parasitizing the Baird's Sandpiper, Calidris bairdii, and the White-rumped Sandpiper, Calidris fuscicollis (Aves: Scolopacidae), from several locations in Patagonia, Argentina. This is the first record of A. comptus in the southern part of South America and from C. fuscicollis and $C$. bairdii, expanding both its geographical and host distribution. Additionally, immature specimens belonging to the genus Profilicollis were found in both bird species.
\end{abstract}

Key words: Arhythmorhynchus; Profilicollis; Calidris bairdii; Calidris fuscicollis; range extension; new records

Shorebirds undertake some of the most spectacular long-distance migrations of any group of birds. These movements initiate in a breeding area and reach a nonbreeding area or wintering locality in an area of food abundance (Piersma et al. 1996). These movements make these birds particularly interesting for the international scientific community because of their migratory behavior as well as on their ecology and biology.

In the Argentine region of Patagonia, several shorebird species use different feeding and breeding sites. Some Nearctic migratory birds nest in the northern hemisphere and migrate to Patagonia during the winter. The Baird's Sandpiper, Calidris bairdii (Coues, 1861), reproduces in the Arctic tundra in the boreal summer and migrates to the southern hemisphere, reaching Patagonia in the early spring. These migrants remain in Argentina and Chile until the beginning of the austral autumn when they return to the Arctic. They are found in a variety of aquatic environments, from sandy beaches and coastal muddy flats to floodable grasslands and marshes. Their diet is based mainly on insects and their larvae, but also includes worms and spiders (Piersma et al. 1996).

The White-rumped Sandpiper, Calidris fuscicollis (Vieillot, 1819), nests from June to August in the central Canadian Arctic, then migrates through central North America, stopping at lakes in Canada. Upon arrival in South America, they migrate through the center of the continent and along its Atlantic coast. They can be seen in Patagonia from March to April on intertidal mudflats, salt marshes, ponds and lagoons. They consume invertebrates such as adult and larval insects, spiders, mollusks, crustaceans, and polychaetes, as well as seeds (Piersma et al. 1996).

The parasitic fauna of migratory birds has been the subject of numerous studies in different parts of the world (e.g., Canaris and Kinsella 2000, 2001, 2007; Canaris et al. 2003; Didyk et al. 2007). However, in South America very little is known about parasites of shorebirds and of seabirds in general. Understanding of parasite life cycles can generate substantial information to understand habitat use and the time spent by the host in a given environment (Bush 1990; Rohde 1993). Studies of the parasitic fauna of these two phylogenetically related species of migratory birds could be an important contribution to ecological and biogeographical studies.

The aim of this paper is to expand the taxonomic and ecological knowledge about helminths of birds associated with wetlands in Argentina. Here we provide new morphological details on Arhythmorhynchus comptus Van Cleave \& Rausch, 1950 based on specimens recovered from Baird's Sandpiper, $C$. bairdii, and the White-rumped Sandpiper, C. fuscicollis, from Patagonia, Argentina, expanding its geographical and host distribution. Additionally, we report immature specimens belonging to the genus Profilicollis Mayer, 1931 found in both bird species.

A total of 44 C. bairdii and 48 C. fuscicollis were 


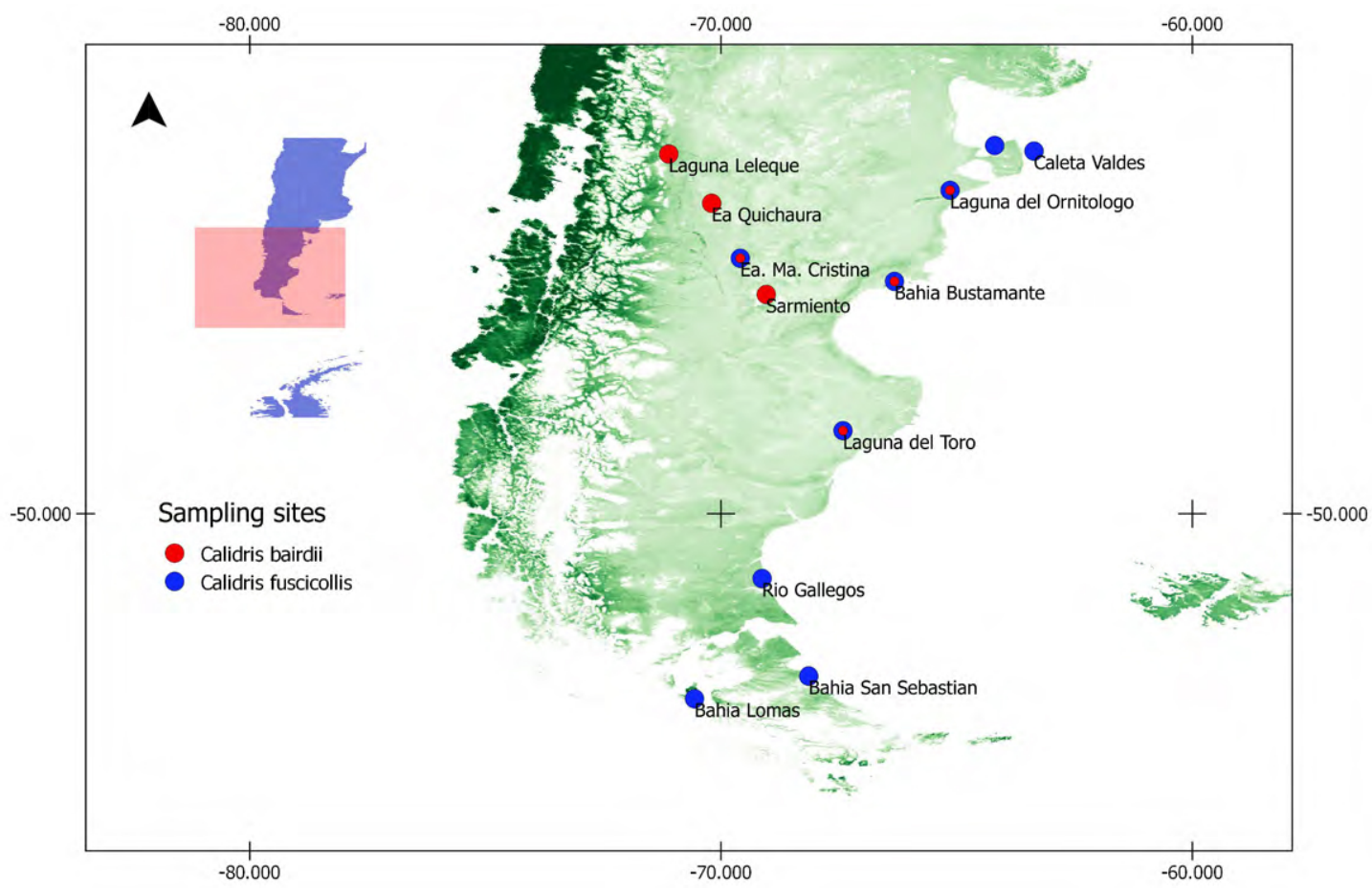

Figure 1. Map of Patagonia, the dots show sampling locations (datum used for geographic coordinates: EPSG: 22185).

occasionally found dead or died of accidents during captures (permits number 19/04, 02/05, 10/6, 02/08, 48/08 DF and FS Chubut), or were collected during other research projects (permits number 406/05 DFS Santa Cruz province, and number 92/05 DF and FS Chubut Province) during January 1999, 2005 and 2006. Samples of hosts were examined from locations in both marine and freshwater environments (Figure 1).

Hosts were dissected in the field and viscera were fixed in $10 \%$ formalin. In the laboratory, acanthocephalans were recovered from the intestine and preserved in $70 \%$ ethanol. Some specimens were not relaxed before fixation and therefore not all had proboscises fully everted. For morphological study, specimens were studied in temporary mounts of lactophenol or eugenol using an Olympus BX51 $1^{\circ}$ microscope (OM). Some male specimens were dissected to a better observation of the cement glands. Several specimens were dried using the critical point method, examined by scanning electron microscopy (SEM) (Jeol 6360LV ${ }^{\circ}$, Tokio, Japan), and photographed. Drawings were made with the aid of a camera lucida. Measurements are given in micrometers unless otherwise indicated as the range followed by parentheses. Eggs were measured through the body wall. For taxonomic identification, acanthocephalans were analyzed following specific bibliography (Van Cleave 1916; Van Cleave and Rausch 1950; Yamaguti 1963; McDonald 1988). The prevalence (P) and mean intensity (MI) were calculated following Bush et al. (1997).

Voucher specimens were deposited in the Colección Helmintológica del Museo de La Plata, Buenos Aires, Argentina, and in the Parasitological Collection of the
Centro Nacional Patagónico, Puerto Madryn, Argentina. A total of 29 adult acanthocephalans were found attached to the intestine wall of $C$. bairdii $(n=21)$ and C. fuscicollis $(n=8)$. Ten immature specimens were also recovered, nine from $C$. bairdii and only one in $C$. fuscicollis. Morphometric and morphological characteristics of adults allowed identification as A. comptus. Immature specimens were identified either as A. comptus or Profilicollis sp.

Arhythmorhynchus comptus Van Cleave \& Rausch, 1950 (Figures 2-5; Table 1): Polymorphida Petrochenko, 1956; Polymorphidae Meyer, 1931; Sphaerechinorhynchinae Golvan, 1960. Arhythmorhynchus Lühe, 1911.

New hosts: Baird's Sandpiper, Calidris bairdii (Coues, 1861); White-rumped Sandpiper, Calidris fuscicollis (Vieillot, 1819).

New localities: Laguna del Toro $\left(48^{\circ} 24^{\prime}\right.$ S, $067^{\circ} 41^{\prime}$ W), Laguna del Ornitólogo ( $43^{\circ} 14^{\prime}$ S, $065^{\circ} 14^{\prime}$ W), Bahía Bustamante ( $45^{\circ} 07^{\prime} 34^{\prime \prime}$ S, $066^{\circ} 32^{\prime} 14^{\prime \prime}$ W), San José Gulf $\left(42^{\circ} 19^{\prime} 5^{\prime \prime}\right.$ S, $\left.064^{\circ} 19^{\prime} 5^{\prime \prime} \mathrm{W}\right)$, Laguna Leleque $\left(42^{\circ} 37^{\prime} 45^{\prime \prime} \mathrm{S}\right.$, $\left.071^{\circ} 11^{\prime} \mathrm{W}\right)$, Estancia Quichaura $\left(43^{\circ} 42^{\prime} \mathrm{S}, 070^{\circ} 02^{\prime} \mathrm{W}\right)$,

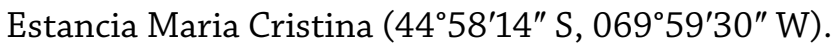

Site of infection: intestine

$\mathrm{P}$ and $\mathrm{MI}=27 \%$ and 1.75 in C. bairdii; $8.3 \%$ and 2 in C. fuscicollis.

Adult specimens - General: Body very long and narrow. Anterior trunk covered by spines in a small area, limited to that region. In the first part, the trunk is widened, then it thins and finally wides again towards the end of the body. Cylindrical posterior portion of the trunk sometimes invaginated in the anterior portion. 

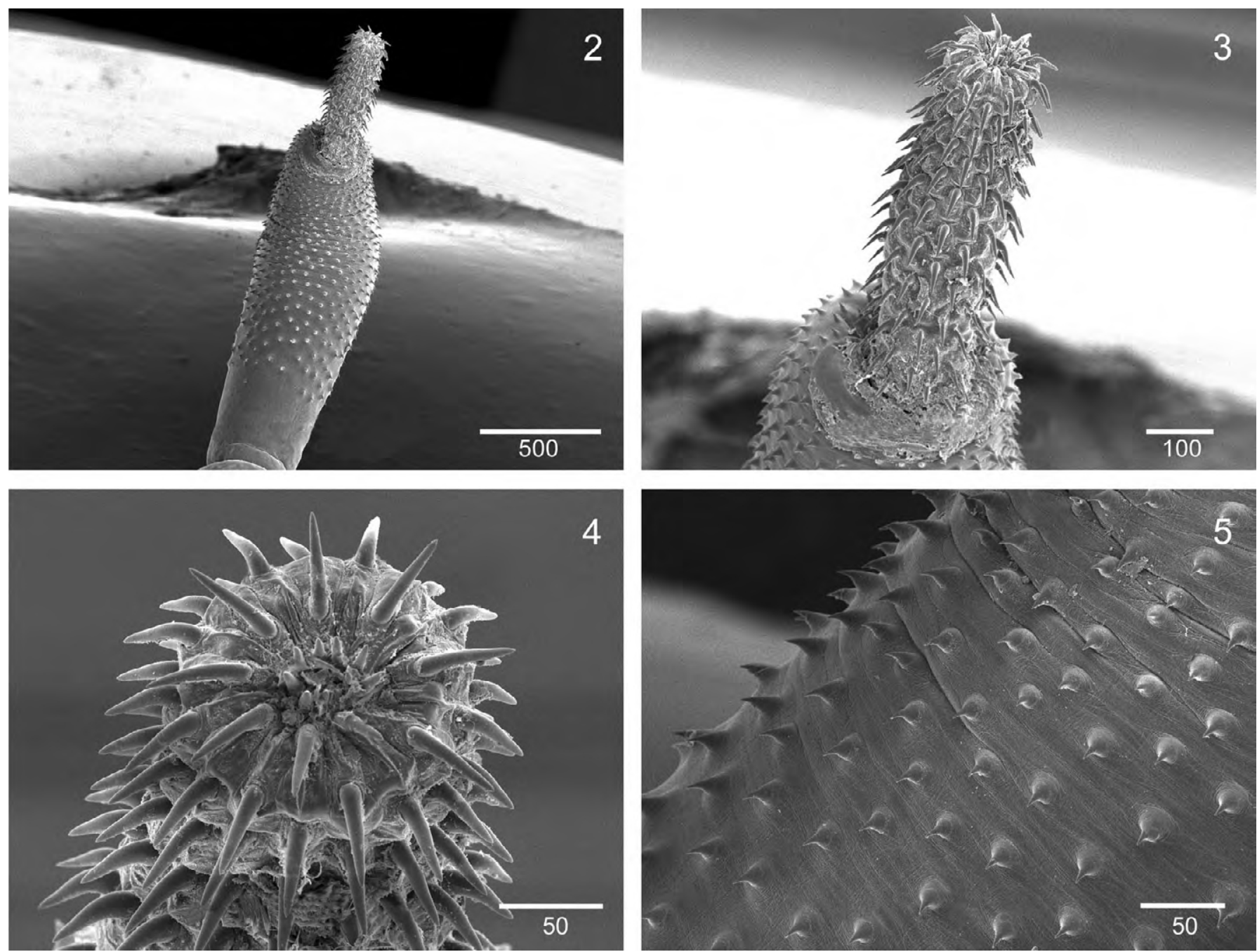

Figures 2-5. Arhythmorhynchus comptus from Calidris bairdii and Calidris fuscicollis from Argentina. 2: General view of $A$. comptus. 3: Proboscis. 4: Proboscis hooks. 5: Anterior body spines.

The proboscis is always swollen medially with 16 or 17 longitudinal rows of hooks, each row with 11 hooks. Hooks longer at the swollen level of the proboscis (45-54). Most proboscis hooks appear to have weak roots. Those of the middle of the proboscis are well rooted (roots: 10-15 long). Receptacle of the proboscis double-walled and cylindrical with ganglia in the middle. Lemnisci narrow. Testes in tandem in the wide posterior region forward to the spinous region. Two number of cement glands. Elliptical eggs with polar extensions of the middle cover.

Immature specimens - Trunk length: 900-1270 (1085), maximum width: 300-500 (396). Proboscis length: 230-350 (280), width 150-250 (187). Proboscis with 14 to 16 rows of hooks and 6-7 hooks per row. The proboscis hooks length: 40-50 (42) long. Spines along the trunk: 20-30 (25) long. In almost all specimens neck length could not be observed due to being inside the trunk. Length of the proboscis receptacle 280-550 (473), width: 60-150 (121).

Host: Calidris bairdii.
Localities: Estancia María Cristina $\left(44^{\circ} 58^{\prime} 14^{\prime \prime}\right.$ S, 069 $\left.59^{\prime} 30^{\prime \prime} \mathrm{W}\right)$ and Bahia Bustamante $\left(45^{\circ} 07^{\prime} 34^{\prime \prime} \mathrm{S}\right.$, $\left.066^{\circ} 32^{\prime} 14^{\prime \prime} \mathrm{W}\right)$, Chubut province, Argentina.

Voucher specimens MLP He 7118, 7119, 7120, 7121, CNP-Par-135 y 136.

Measurements of males and females, of A. comptus are shown in Table 1.

\section{Profilicollis sp. immature specimens (Figure 6)}

Undeveloped reproductive organs were observed. Short and stocky trunk. Length: 1500-2750 (1987), maximum width: 700-1000 (825). Length of proboscis 600-700 (650), width 400-500 (450). Proboscis with 16-20 rows of hooks and 7-8 rows of hooks per row. Length of proboscis hooks: 50 . Length of trunk spines: 20-50 (31). Neck long: 600-1800 (975), width: 300; length of the proboscis receptacle 450-800 (675), width: 200-300 (250).

Hosts: Calidris bairdii and Calidris fuscicollis.

Locality: Bahía Bustamante (4507'34" S, 066 32'14" W), Chubut province, Argentina. 
Table 1. Comparative measurements of Arhythmorhynchus spp. from different hosts and localities. References: L (length), W (width)

\begin{tabular}{|c|c|c|c|}
\hline Host species & $\begin{array}{l}\text { Calidris ptilocnemis couesi/Calidris } \\
\text { alpina pacifica/Aphriza virgata/ } \\
\text { Numenius americanus }\end{array}$ & Calidris bairdii & Calidris fuscicollis \\
\hline Distribution & Alaska & $\begin{array}{l}\text { Ea. Ma. Cristina/Ea Quichaura/ B. } \\
\text { Bustamante/ Lag. Leleque }\end{array}$ & $\begin{array}{l}\text { Lag. del Toro/B. Bustamante/ San José } \\
\text { Gulf/ Lag. del Ornitólogo }\end{array}$ \\
\hline References & Van Cleave \& Rausch, 1950 & Present study & Present study \\
\hline Males (n) & - & 4 & 3 \\
\hline Total L & $23-32 \mathrm{~mm}$ & $13-28.4(20.6) \mathrm{mm}$ & $19.1-21.6(20.4) \mathrm{mm}$ \\
\hline Total W & $635-807$ & $400-700(513)$ & 500 \\
\hline Proboscis L & $320-440$ & $410-500(453)$ & $450-550(483)$ \\
\hline Proboscis W & $170-240$ & $130-200(183)$ & $120-200(178)$ \\
\hline Proboscis receptacle L & - & $700-1300(1030)$ & $700-1300$ \\
\hline Proboscis receptacle W & - & $150-500(288)$ & $120-200(207)$ \\
\hline Row of hooks & $15-16$ & $16-17$ & $16-17$ \\
\hline Hooks per row & $8-9$ & $11-12$ & $11-12$ \\
\hline Hooks L & $44-48$ & $0.040-0.053(0.053)$ & $0.040-0.046(0.042)$ \\
\hline Neck L & $350-750$ & 325 & $100-250(167)$ \\
\hline Neck W & - & 300 & $120-200(173)$ \\
\hline Body spines L & 15 & $20-30(25)$ & $25-40(33)$ \\
\hline Body spines W & $15-20$ & $20-40(30)$ & $20-25(21.6)$ \\
\hline Lemnisci L & $1.2-1.8 \mathrm{~mm}$ & $700-1300(1030)$ & $1.1-1.85(1.38) \mathrm{mm}$ \\
\hline Anterior testis $\mathrm{L}$ & $1-1.5 \mathrm{~mm}$ & $370-1100(668)$ & $300-850(575)$ \\
\hline Anterior testis W & - & $140-350(248)$ & $200-250(225)$ \\
\hline Distance from spiny area & $2-3 \mathrm{~mm}$ & $1.11-3.0 \mathrm{~mm}$ & $1.4-2.1 \mathrm{~mm}$ \\
\hline Posterior testis $\mathrm{L}$ & $1-1.5 \mathrm{~mm}$ & $550-1200(738)$ & $320-1000(660)$ \\
\hline Posterior testis W & - & $190-350(260)$ & $200-220(210)$ \\
\hline Cement glands L & $13-24 \mathrm{~mm}$ & $12.4-23.1(14.9) \mathrm{mm}$ & $14.1 \mathrm{~mm}$ \\
\hline Females (n) & & 4 & 3 \\
\hline Total L & $40-55 \mathrm{~mm}$ & $17.700-32.65(25.013) \mathrm{mm}$ & $26.95-30.2(28.36) \mathrm{mm}$ \\
\hline Total W & $800-1000$ & $450-950(613)$ & $480-600(527)$ \\
\hline Proboscis L & $430-480$ & $400-750(600)$ & $450-600(517)$ \\
\hline Proboscis W & $250-400$ & $160-190(150)$ & 200 \\
\hline Proboscis receptacle L & - & $1.290-1.75(1.455) \mathrm{mm}$ & $1-1.7(1.28) \mathrm{mm}$ \\
\hline Proboscis receptacle W & - & $100-300(213)$ & $200-250(217)$ \\
\hline Row of hooks & $15-16$ & $16-17$ & $16-17$ \\
\hline Hooks per row & $8-9$ & $11-12$ & $11-12$ \\
\hline Hooks L & - & $0.042-0.050(0.045)$ & $0.045-0.060(0.054)$ \\
\hline Neck L & $460-800$ & $250-280(265)$ & $100-300(158)$ \\
\hline Neck W & - & $200-370(285)$ & $200-350(283)$ \\
\hline Body spines L & - & $20-30(27)$ & $20-35(25)$ \\
\hline Body spines W & - & $15-25(20)$ & $20-25(22)$ \\
\hline Lemnisci L & - & $1.3-2.1(1.7) \mathrm{mm}$ & $1.1-1.2(1.15) \mathrm{mm}$ \\
\hline Eggs & $93-101 \times 22-26$ & $90-100 \times 20-25$ & $90-100 \times 20-25$ \\
\hline
\end{tabular}

Voucher specimens MLP He 7116, 7117 and CNP 137. Morphometric and morphologic characteristics of adult acanthocephalans studied here enable them to be identified as A. comptus. However, slight differences in measurements of some features from those recorded by previous authors were observed (e.g., total length of female, neck length, body spine length, number of hook per row) (see Table 1). In present specimens it could be observed a great number of hooks per row than those observed by Van Cleave and Rausch (1950). The present specimens show some similarities to Arhythmorhynchus capellae (Yamaguti, 1935) and Arhythmorhynchus eroliae (Yamaguti, 1939). However, the two latter species have larger number of rows and hooks per row than A. camptus, which has the lowest number of hooks per row in the genus. Although there are other reports of
A. comptus, authors did not provide morphometric data (e.g., Canaris and Kinsella 2007) that could be compared with the present specimens.

There are discrepancies in the number of cement glands in this species and in others of the genus (Golvan 1960; Yamaguti 1963). However, the observation of such structures is quiet difficult due to the thickness of the body wall. We observed only two cement glands after the dissection of some males. According to Van Cleave and Rausch (1950), A. comptus is the only species of the genus with two cement glands.

Members of the genus have been recorded previously in North and Central America in birds of the family Scolopacidae. In Alaska A. eroliae was reported from the Ruddy Turnstone Arenaria interpres (Linnaeus, 1758) (Canaris and Kinsella 2007), and A. longicollis (Villot, 


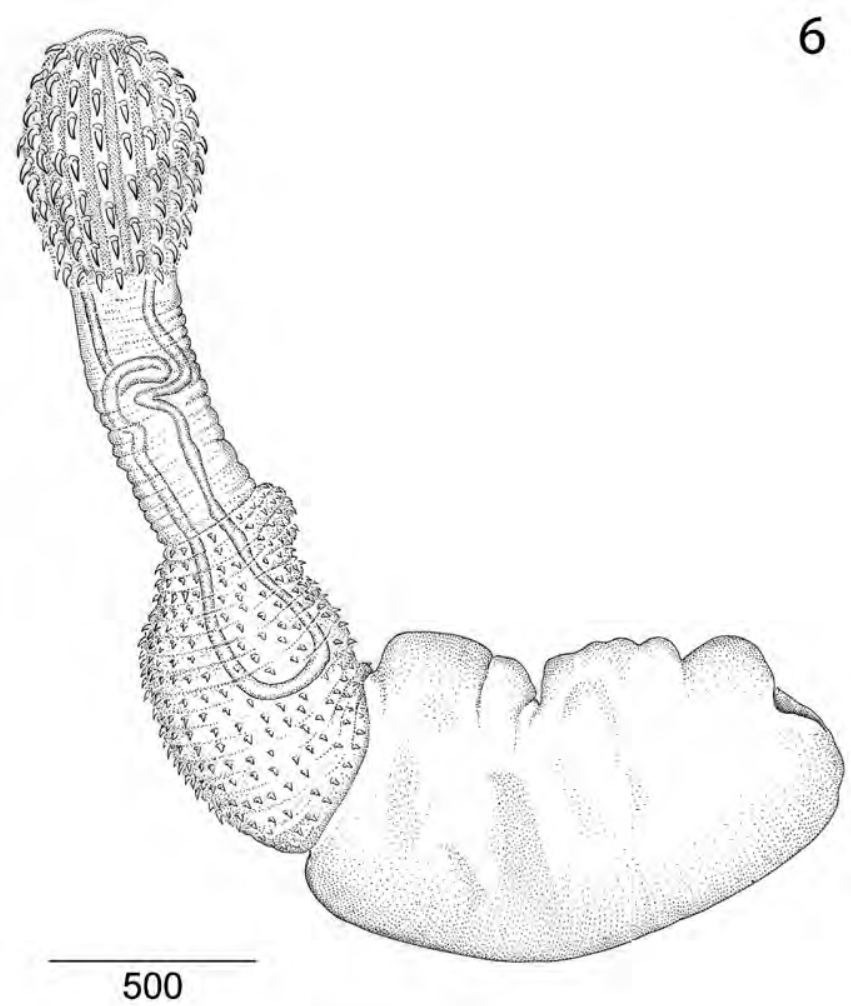

Figure 6. Profilicollis sp. Immature specimen from Calidris bairdii and Calidris fuscicollis from Argentina.

1875) in the Ruddy Turnstone and White-rumped Sandpiper in Belize (Canaris and Kinsella 2001). This last two acanthocephalan species can also be distinguished from $A$. comptus by the number and distribution of the proboscis hooks (see Table 1 ).

This is the first record of $A$. comptus from both $C$. bairdii and $C$. fuscicollis as well as the first record in any host from South America.

The genus Profilicollis includes nine valid species of which only four occur in South America (Amin 2013). Profilicollis sphaerocephalus Van Cleave, 1947 has been recorded in Uruguay and South Australia (Zdzitowiecki 1985), Profilicollis antarcticus Zdzitowiecki, 1985 was recorded in the South Shetland Islands (Zdzitowiecki 1985), Chile Islands (Pulgar et al. 1995), New Zealand (Brockerhoff and Smales 2002), and Patagonia (Kreiter and Semenas 1997). Profilicollis altmani (Perry, 1942) has been recorded in Perú (Tantaleán and Cárdenas 2004) and Chile (Oliva et al. 2008). Finally, Profilicollis chasmagnathi (Holcman-Spector, Mane-Garzon \& DeiCas, 1978) was recorded in Brazil (Yamaguti 1963), Uruguay (Cordero 1933) and Argentina (Martorelli 1989; Vizcaino 1989; Diaz 2006, La Sala and Martorelli 2007; Diaz et al. 2011). Because no adults were found, it was not possible to identify the specimens to species level. However, based on the number and distribution of hooks on the proboscis and previous reports in the area (i.e., South Atlantic coast), it is probable that they are $P$. chasmagnathi. However, further experimental or molecular studies are needed to confirm this hypothesis and to corroborate the identity of the species.

Baird's and White-rumped sandpipers breed in the high Arctic and migrate extremely long distances to winter in the southern cone of South America (Chandler 2009). The birds arrive in northern South America around early October and to their wintering areas (e.g., Patagonia Argentina) about a month later. According to Atrashkevich (1979), the life cycle of A. comptus includes freshwater isopods as intermediate hosts. Development from the infective cystacanth to the adult acanthocephalan takes around 30-49 days (Atrashkevich 1979). Because both adults and juveniles were found in birds from Patagonia collected in January, then infections were acquired in South America during the fall migration. Future studies are needed to show whether the life cycle can also be completed on the wintering grounds.

Previous to this work, there have been few records of parasites in these two Nearctic migratory shorebirds species in southernmost South America. They included the nematodes Echinuria skrjabiniensis Efimov in Skrjabin, Sobolev \& Ivashkin, 1965 (Acuariidae) from C. bairdii and C. fuscicollis, and Tetrameres megaphasmidiata Cremonte, Digiani, Bala \& Navone, 2001 (Tetrameridae) in C. fuscicollis both from Patagonia, Argentina (Cremonte et al. 2001; Diaz et al. 2011).

The present report increases the knowledge of acanthocephalans of migratory birds and represents the first record of A. comptus in South America and from C. fuscicollis and C. bairdii, expanding both the geographical and host distribution.

\section{ACKNOWLEDGEMENTS}

We would like to thank Monica Abril, Graciela Escudero and Marcelo Bertellotti for providing us the hosts, Guillermo Panisse for his help processing the hosts, Patricia Sarmiento from the Servicio de Microscopía Electrónica de Barrido del Museo de La Plata and María Cristina Estivariz for the drawing. We specially thank John Mike Kinsella for his help in the English revision of the manuscript. Fieldwork was conducted with permits from the Secretaría de Turismo y Áreas Protegidas, Chubut. Funding was provided by ANPCyT (PICT 525) and partially by CONICET (PIP 698), and UNLP (N628 and N758).

\section{LITERATURE CITED}

Amin, O.M. 1992. Review of the genus Polymorphus Lühe, 1911 (Acanthocephala: Polymorphidae), with the synonymization of Hexaglandula Petrochenko, 1950 and Subcorynosoma Hoklova, 1967 and key to the species. Qatar University Science Journal 12: 115-123. http://qspace.qu.edu.qa/handle/10576/9865

Amin, O.M. 2013. Classification of the Acanthocephala. Folia Parasitologica 60(4): 273-305. doi: 10.14411/fp.2013.031 
Atrashkevich, G.I. 1979. Post-embrionic development of Arhythmorhynchus petrochenkoi Schmidt 1969 (Acanthocephala: Polymorphidae); pp. 81-92, in: Ekologiya I morfologiya gel'mintov pozvonochnykh chukotki. Moscow: Nauka.

Brockerhoff, A.M. and L.R. Smales. 2002. Profilicollis novaezelandesis n. sp. (Polymorphidae) and two other acanthocephalan parasites from shorebirds (Hematopodidae and Scolopacidae) in New Zealand, with records of two species in intertidal crabs (Decapoda: Grapsidae and Ocypodidae). Systematic Parasitology 52(1): 55-65. doi: 10.1023/A:1015011112900

Bush, A.O.1990. Helminth communities in avian hosts: determinants of patterns; pp. 197-232, in: G.W. Esch, A.O. Bush and J.M. Aho. Parasite communities: patterns and processes. London: Chapman and Hall. doi: 10.1007/978-94-009-0837-6_8

Bush, A.O., K.D. Lafferty, J.M. Lotz, and A.W. Shostak. 1997. Parasitology meets ecology on its own terms: Margolis et al. revisited. Journal of Parasitology 83: 575-583. http://www.jstor.org/ stable/3284227

Canaris, A.G. and J.M. Kinsella. 2000. Helminth parasites in six species of shorebirds (Charadrii) from Bristol Bay, Alaska, U.S.A. Comparative Parasitology 67: 250-252.

Canaris, A.G. and J.M. Kinsella. 2001. Helminths parasites in six species of shorebirds (Charadrii) from the Coast of Belize. Memorias do Instituto Oswaldo Cruz 96: 827-830. doi: 10.1590/ S0074-02762001000600015

Canaris, A.G., J.M. KinsellaandR. Braby. 2003. Helminth parasitecommunities in two species of shorebirds (Charadrii) from Namibia Comparative Parasitology 70:1 55-161. doi: 10.1654/4069

Canaris, A.G. and J.M. Kinsella, 2007. Helminth communities of three sympatric species of shorebirds (charadrii) from four summer seasons at Bristol Bay, Alaska. Journal of Parasitology: 93: 485-490. doi: 10.1645/GE-3550.1

Chandler, R. 2009. Shorebirds of North America, Europe, and Asia: a photographic guide. Princeton and Oxford: Princeton University Press. 448 pp.

Cremonte, F., M.C. Digiani, L.O. Bala and G.T. Navone. 2001 Tetrameres (Tetrameres) megaphasmidiatan. sp. (Nematoda: Tetrameridae), a parasite of the Two-banded Plover, Charadrius falklandicus, and White-rumped Sandpiper, Calidris fuscicollis, from Patagonia, Argentina. Journal of Parasitology 87(1): 148-51. doi: 10.1645/0022-3395(2001)087[0148:TTMNSN]2.0.CO;2

Cordero, E. 1933. Sur quelques acanthocephales de l'Amerique meridionale. Annales de Parasitologie Humaine et Comparée 2: 271-279.

Didyk, A.S., A.G. Canaris and J.M. Kinsella. 2007. Intestinal helminths of the Spotted Sandpiper, Actitis macularius (L.), during fall migration in New Brunswick, Canada, with a checklist of helminths reported from this host. Comparative Parasitology 74(2): 359-363. doi: 10.1654/4280.1

Diaz, J.I. 2006. Las comunidades parasitarias como expresión de distinto comportamiento trófico en aves del Mar Argentino [Doctoral Thesis]. La Plata: Universidad Nacional de La Plata. 259 pp. http://sedici.unlp.edu.ar/handle/10915/4288

Diaz, J.I., G. Panisse, G. Escudero and J.M. Kinsella. 2011. New host and geographical records and morphological details for Echinuria skrjabiniensis (Nematoda, Acuariidae) from shorebirds in Argentina. Acta Parasitologica 56(3): 315-319. doi: 10.2478/ s11686-011-0063-5

Golvan, Y.J. 1960. Le phylum des Acanthocephala. Troisieme note. La clase des Palaeacanthocephala (Meyer, 1931). Annales de Parasitologie Humaine et Comparée 35(3): 350-386.

Kreiter, A. and L. Semenas. 1997. Helmintos parásitos de Larus dominicanus en la Patagonia Argentina. Boletín Chileno de Parasitología 52: 39-42.
La Sala, L.F. and S.R. Martorelli. 2007. Intestinal acanthocephaladiosis in Olrog's Gulls (Larus atlanticus): Profilicollis chasmagnathi as possible cause of death. Journal of Wildlife Diseases 43(2): 269-273. doi: 10.7589/0090-3558-43.2.269

Martorelli, S.R. 1989. The role of Cytograpsus angulatus (Crustacea; Brachyura) in the life cycles of Microphallus szidati (Digenea; Microphallidae) and Falsifilicollis chasmagnathi (Acanthocephala; Filicollidae): some aspects of their ecological parasitology. Memórias do Instituto Oswaldo Cruz 84(4): 567-574. doi: 10.1590/S0074-02761989000400016

McDonald, M.E. 1988. Key to Acanthocephala Reported in Waterfowl. Resource Publication, no. 173, U.S. Fish and Wildlife Service, Washington, DC, USA.

Oliva, M.E., I. Barrios, S. Thatje and J. Laudien. 2008. Changes in prevalence and intensity of infection of Profilicollis altmani (Perry, 1942) cystacanth (Acanthocephala) parasitizing the mole crab Emerita analoga (Stimpson, 1857): an El Niño cascade effect? Helgoland Marine Research 62(1): 57. doi: 10.1007/s10152-0070082-7

Piersma, T., J. Van Gils and P. Wiersma. 1996. Family Scolopacidae (sandpipers, snipes and phalaropes); pp. 444-533, in: J. del Hoyo, A. Elliott and J. Sargatal. Handbook of the birds of the world. Hoatzin to auks. Barcelona: Lynx Edicions.

Pulgar, J., M. Aldana, E. Vergara and M. George-Nascimento. 1995. La conducta de la jaiba estuarina Hemigrapsus crenulatus (MilneEdwards 1837) en relación al parasitismo por el acantocéfalo Profilicollis antarcticus (Zdzitowiecki 1985) en el sur de Chile. Revista Chilena de Historia Natural 68: 439-450. http://www. uv.mx/personal/tcarmona/files/2010/08/Pulgar-etal-1995.pdf

Rohde, K. 1993. Ecology of marine parasites. Wallingford, Oxo'n, UK: CAB International. 298 pp.

Tantaleán, V.M. and J. Cárdenas. 2004. Consideraciones sobre Profilicollis altmani (Perry, 1942) Van Cleave, 1947 en el Perú. Revista Peruana de Biología 11(1): 109-111. http://www.scielo.org.pe/ scielo.php?script=sci_arttext\&pid=S1727-99332004000100016

Van Cleave, H.J. 1916. A revision of the genus Arhythmorhynchus, with descriptions of two new species from North American birds. Journal of Parasitology 2(4): 167-174. http://www.jstor. org/stable/3270906

Van Cleave, H.J. and R.L. Rausch. 1950. A new species of the acanthocephalan genus Arhythmorhynchus from sandpipers of Alaska. Journal of Parasitology 36: 278-283. http://digitalcommons. unl.edu/cgi/viewcontent.cgi?article=1394\&context=parasitolog yfacpubs

Vizcaino, S.I. 1989. Acanthocephalan parasites of Argentine birds I. Morphological complements to the knowledge of Polymorphus (Profilicollis) chasmagnathi comb. nov. (Polymorphidae). Studies on Neotropical Fauna and Environment 24(4): 189-192. doi: 10.1080/01650528909360790

Yamaguti, S. 1963. Systema helminthum. Volume V. Acanthocephala, Intersci. New York: John Wiley \& Sons. 423 pp.

Yoshino T., S. Nakamura, D. Endoh, M. Onuma, Y. Osa, H. Teraoka, T. Kuwana and M. Asakawa. 2009. A helminthological survey of four families of waterfowl (Ardeidae, Rallidae, Scolopacidae and Phalaropodidae) from Hokkaido, Japan. Journal of the Yamashina Institute Ornithology 41 (1): 42-54. doi: http:// dx.doi.org/10.3312/jyio.41.42

Zdzitowiecki, Z. 1985. Acanthocephalans of birds from South Shetlands (Antarctic). Acta Parasitological Polonica 30(2): 11-24.

Received: 29 December 2015

Accepted: 24 May 2016

Academic editor: Sandra Costa-Böddeker 